\title{
Dokument nowożytny - obiektem XX-wiecznych studiów aktoznawczych w Europie
}

Zarówno archiwiści, jak i dyplomatycy wspomagający współczesnego historyka w jego zmaganiach z nowożytnym źródłem dokumentowym starają się, co oczywiste, wypracować optymalną formułę postępowania $\mathrm{z}$ bezpośrednim przekazem, dostosowania jej do najnowszych potrzeb i możliwości udostępniania i przetwarzania dokumentów, wypełniającej je treści, warstwy informacyjnej. Czują się, rzecz jasna, również zobowiązani do praktycznego odczytania, stosownej reinterpretacji dotychczasowych studiów nad dokumentem posiadających przecież już kilkusetletnią tradycję.

Spadkobiercy klasycznej wizji studiów dyplomatycznych wypracowanej w stuleciu krytyki erudycyjnej a zdefiniowanej przez J. Mabillona zawęzili analizę źródeł do dyplomu - czyli dokumentu w ścisłym tego słowa znaczeniu. Wiek XIX przyniósł z kolei ugruntowanie stanowiska, iż dyplomatyka winna zajmować się dokumentami. W drugiej połowie tego stulecia w publikacjach niemieckich zaczęto nawet stosować nowy termin dla dyplomatyki: Urkundenlehre. Jeszcze w 1907 r. O. Redlich wyraźnie wyłączył z zakresu dyplomatyki badania jakichkolwiek akt nie posiadających charakteru ściśle prawnego, jak: raporty, korespondencja, protokóły, rachunki itp.

Równolegle jednak w literaturze europejskiej ujawniać zaczynają się odmienne tendencje wskazujące na potrzebę rozszerzenia badań dyplomatycznych na materiały pokrewne właściwemu dokumentowi. Niemiecki autor H. Steinacker i Francuz A. Dumas w latach dwudziestych naszego stulecia zaproponowali poszerzoną definicję dokumentu o wszystkie kategorie źródeł aktowych ${ }^{1}$.

\section{„Aktenkunde”}

Ton, zakres problemowy, wysoką rangę XX-wiecznym studiom nad dokumentem nadał w pierwszym rzędzie H. O. Meisner. Pracownik Tajnego Archiwum w Berlin Dahlem, tworzył wspólnie z A. Brenneke silny tandem berliń-

${ }^{1}$ A. Tomczak, W sprawie zakresu dyplomatyki, [w:] Pamiętnik X Powszechnego Zjazdu Historyków Polskich w Lublinie 17-21 września 1968 r., s. 330-343. 
skiego Instytutu Archiwistyki. Po wojnie (od 1953 r.) uprawiał źródłoznawstwo z pozycji profesora berlińskiego uniwersytetu. Zaliczany jest do najbardziej dociekliwych umysłów najnowszej archiwistyki. Penetrował, zwłaszcza w początkowej fazie naukowej kariery, te pola archiwalnej działalności, które pozostawały poza głównym nurtem dotychczasowych zainteresowań badawczych. Warto podkreślić, że najpoważniejsza jego publikacja z lat trzydziestych - „Aktenkunde" - ukazała się jeszcze przed głośnymi wykładami A. Brenneke we wspomnianym Instytucie.

Ten pierwszy podręcznik Meisnera zaskoczył społeczność archiwalną. W Polsce wywołał wręcz konsternację. $\mathrm{Z}$ widoczną niechęcią przyjmowano lansowaną przez Meisnera tezę o potrzebie wyodrębnienia nowej dyscypliny naukowej zajmującej się zagadnieniem aktu i miejscem jego powstania - kancelarią. F. Pohorecki, recenzujący książkę, podkreślał co prawda daleko idące nowatorstwo pracy, która jednak ,nie pokrywała się treścią z żadnym z dotąd wydanym podręcznikiem"”.

Pomysł badawczy Meisnera zrodził się z potrzeby, dostrzeganej także przez innych wybitnych autorów międzywojnia (jak chociażby E. Casanovę i A. Brenneke), uświadomienia czytelnikom skutków płynących ze zderzenia, przeciwstawienia klasycznej dokumentacji wytwarzanej przez kancelarie średniowieczne $\mathrm{z}$ najnowszymi materiałami narastającymi w systemie akt spraw. Te ostatnie postrzegał w kontekście zasadniczych przeobrażeń biurokratyczno-administracyjnych zarysowujących się w Europie po Rewolucji Francuskiej. Następujące w ślad za tymi procesami dynamiczne przewartościowania cywilizacyjne i społeczno-ekonomiczne $\mathrm{w}$ istotny sposób wpływały na ówczesną produkcję aktową: tak od strony ilościowej jak i formy kancelaryjnej. Wiedza dyplomatyczna wyniesiona $\mathrm{z}$ tradycyjnych studiów historycznych i budowana na podstawie zachowanych źródeł średniowiecznych okazywała się w zetnięciu z nowszymi aktami mało przydatna. W odróżnieniu jednak od A. Brenneke uważał, iż opanowanie tych masowo powstających materiałów było możliwe jedynie drogą specjalistycznych studiów uwzględniających istotę, specyficzny charakter akt XIX i XX-wiecznych. Wymagało po prostu uchwycenia najważniejszych cech wyróżniających te akta spośród starszych dokumentów.

Meisner podjął trop wskazany przez swego rodaka - wspomnianego tu Steinackera oraz francuskiego dyplomatyka Dumasa. Nowatorstwo jego koncepcji stanowi jednak pochodną podjętej przez autora ambitnej próby ześrodkowania na gruncie studiów aktoznawczych doświadczeń badawczych dyplomatyki i archiwistyki. Uznał, że wypracowana w ten sposób metoda analizy akt pozwoli na wyodrębnienie osobnej dyscypliny, którą nazwał nauką o akcie - Aktenkunde. Termin ten umieścił w tytule cytowanego już podręcznika z 1935 r. traktując go w pracy zamiennie z określeniem ,moderne Urkundenlehre”. Definicja aktu

${ }^{2}$ H.O. Meisner, Aktenkunde, Berlin 1935; F. Pohorecki, Recenzja podręcznika Meisnera, „Archeion”, t. 15,1937/1938. 
natomiast sprecyzowana została w drugim rozdziale pracy obejmującym kwestie terminologiczne. Za W. Bauerem przedstawia akt jako „pismo niesamoistne”, które powinno być oceniane tylko w zestawieniu z innymi aktami narastającymi w toku załatwiania danej sprawy. W przeciwieństwie do akt dyplom, z racji swych oficjalnych funkcji, posiada swój ,,samoistny, indywidualny byt”.

Tego typu interpretacja niosła dalsze konsekwencje, otwierała rozległa perspektywę poznawczą powodując włączenie w krąg badań aktoznawczych studiów nad problemem rekonstrukcji procesu powstawania akt w urzędzie i kancelarii. Akt traktowany jest jako element składowy pism grupowanych w większe całości: akta danej sprawy, ciagi spraw tworzących teczki itp. Dodajmy, że program nauki o akcie obejmować miał przede wszystkim dwa zagadnienia: genezę akt oraz rodzaje akt i ich klasyfikację ${ }^{3}$. Stosownie do tych genetycznotypologicznych celów poznawczych pomyślana została konstrukcja pracy, którą jednak, z braku miejsca, nie będziemy się tu zajmować.

Nie sposób wszakże nie wspomnieć o atmosferze jaka zaczęła narastać wokół meisnerowskiej koncepcji genetyki akt. Wrażenie zaskoczenia pomysłami Meisnera widoczne w piśmiennictwie europejskim wymaga komentarza, przeniesienia się w pozamaterialną sferę zawodowej percepcji archiwistów czy naukowych preferencji w archiwistyce przed drugą wojną światową i kilku pierwszych latach po jej zakończeniu. Obstający przy ewolucyjno-genetycznym podejściu do źródła historycznego H.O. Meisner musiał niejako przyjmować na siebie zarzuty jakie głównie neopozytwiści i reprezentanci szkoły „Annales” kierowali przeciw pruskiej tradycji badań źródłoznawczych. Jednoznaczna deklaracja metodologiczna Meisnera mogła wywołać w Europie pewne uprzedzenie do „Aktenkunde”, skłaniać do interpretacji prezentowanych w nim poglądów przez pryzmat własnych preferencji metodologicznych czytelników. Nie dla wszystkich jasno przedstawiał się problem miejsca „,nauki o akcie” wśród nauk pomocniczych historii. Rodziły się, siłą rzeczy, dalsze pytania, na które odpowiedź mogła przynieść spokojna, wyważona refleksja wymagająca, jak wiadomo, czasu.

Meisner wysunął z tych doświadczeń niezbędne wnioski. Jego następna książka, wydana z początkiem lat pięćdziesiątych, spotkała się już ze spokojniejszym odzewem. Autor zamienił tym razem termin „Aktenkunde” na „Urkunden und Aktenlehre der Neuzeit”. Ten formalny, przyznajmy, zabieg wskazuje jednak na to, że autorowi zależało na nieco innym niż poprzednio rozłożeniu akcentów. Uznał za zbędne podtrzymywanie swej pierwotnej koncepcji wyodrębnienia nauki o akcie w samodzielną naukę pomocniczą historii. Zawęża zakres znaczeniowy średniowiecznego dyplomu (dokumentu) utożsamiając go ze świadectwem. Przypomina, że średniowiecze nie znało pojęcia ,akt” (lub „akta”). Termin ten pojawił się dopiero około 1600 r. w sądownictwie, upowszechnił się następnie w innych urzędach. W praktyce kancelaryjnej najbliż-

${ }^{3}$ W. Bauer, Einfuhrung in das Studium der Geschichte, Tubingen 1921, s. 249. 
szych stuleci zaczyna zacierać się różnica w potocznym rozumieniu obu form: dokumentu i aktu. Zastrzega się jednak, że istota funkcji akt i dokumentu nadal pozostawała odrębna: te pierwsze spełniały rolę środka do celu, impulsu do podjęcia decyzji, a dokument stanowi ślad końcowej fazy wcześniejszych czynności - decyzję, będąc tym samym samoistnym tworem urzędowym ${ }^{4}$.

$\mathrm{Z}$ uwagi na to, że problem genetyki akt tkwił głęboko w niemieckiej tradycji metodologicznej koncepcje Meisnera przyjmowane były w tutejszej literaturze archiwalnej ze szczególnym zainteresowaniem. Polemikę z nim podjął E. Neuss, specjalizujący się w archiwaliach gospodarczych. Wychodził z założenia, że akta przedsiębiorstw stanowią w znacznej mierze przeciwieństwo akt urzędów administracyjnych. Bardzo krytycznie zwłaszcza odniósł się Neuss do możliwości zastosowania „teoretycznej konstrukcji” Meisnera w odniesieniu do akt przemysłowych wytworzonych po roku 1945 w państwach Europy środkowo-wschodniej. Uznał, że Meisner oparł się w swoich poszukiwaniach badawczych na doświadczeniach niemieckich $\mathrm{z}$ okresu kapitalizmu. Zdaniem tego czołowego wschodnioniemieckiego archiwisty doktryna socjalistyczna przyniosła inne jakościowo rozwiązania w dziedzinie zarządzania gospodarką, co rzutowało $\mathrm{z}$ kolei na formę i treść narastających akt ${ }^{5}$.

Ze zdecydowaną obroną genetycznej koncepcji H.O. Meisnera wystapili autorzy zbiorowej publikacji książkowej wydanej $\mathrm{z}$ okazji 65. rocznicy urodzin tego archiwisty ${ }^{6}$. Reprezentatywny wydaje się zwłaszcza głos W. Leescha, uchodzącego za kontynuatora teoretycznej myśli A. Brenneke i współpracującego przez wiele dziesięcioleci z Meisnerem. Zarówno historyk jak i archiwista zobowiązani sa, według Leescha, do ustalenia genetycznego związku między źródłami (aktami). Na tej podstawie właśnie historyk rekonstruuje minioną rzeczywistość, a archiwista „przekształca chaotyczną masę akt w spójną strukturę”, określa „kancelaryjno-rzeczowy” związek między pismami, teczkami i grupami aktowymi. Znajomość genetyki akt pozwala archiwiście uchwycić znaczenie danych grup akt w całości produkcji aktowej wytwórcy - czyli w przyszłym zespole archiwalnym. Zbliżoną argumentacją posługuje się także zasłużony, zachodnioniemiecki archiwista J. Papritz, dla którego genetyczne kryterium oceny procesu aktotwórczego stanowić może w dalszym ciągu bardzo ciekawe odniesienie dla studiów nad kancelarią i zespołem archiwalnym? ${ }^{7}$.

Kolejne dziesięciolecie zamknął Meisner następną książką, trzecią edycją swojego podręcznika archiwistyki ${ }^{8}$. Tym razem wyeksponował Meisner w tytule pojęcie „Archivalienkunde”. Uznał za niecelowe przeciwstawianie dyplomatyce

\footnotetext{
${ }^{4}$ H.O. Meisner, Urkunden und Aktenlehre der Neuzeit, Leipzig 1950. II wyd. 1952, s. 18.

${ }^{5}$ E. Neuss, Aktenkunde der Wirtschaft, t. 1 i t. 2, Berlin 1954, 1956.

${ }^{6}$ Archivar und Historiker. Studien zur Archiv und Geschichtswissenschaft, red. H. Lotzje i H.S. Brather, Berlin 1956.

${ }^{7}$ W. Leesch, Methodik, Gliederung und Bedeutung der Archivwissenschaft, tamże, s. 13-26; J. Papritz, Grunfragen der Archivwissenschaft, „Archivalische Zeitschrift”, t. 52,1956.

${ }^{8}$ H.O. Meisner, Archivalienkunde vom 16, Jahrhundert bis 1918, Leipzig 1969.
} 
naukę o akcie. Bezzasadnym zwłaszcza było według niego podtrzymywanie chronologicznej cezury wyznaczającej zasięg studiów nad dyplomami i aktami. Nie czuł się już teraz odosobniony ze swymi dylematami. Mógł w pierwszym rzędzie odwołać się do poglądów W. Leescha, który sprzeciwił się formalnym kryteriom rozdziału nauk pomocniczych historii. Opowiadał się raczej za rzeczowymi przesłankami precyzyjnego określenia przedmiotu danej dyscypliny, $\mathrm{z}$ którego z kolei wynika zakres badawczy każdej nauki.

Meisner odrzucił teraz proponowany w poprzednim podręczniku rok 1500 jako datę graniczną między okresem dyplomów a okresem akt. Przyjął stanowisko, że dopiero ewentualnie rok 1918 zapoczątkowuje nowy okres w rozwoju akt. Pojęciem nadrzędnym dla dyplomatyki i nauki o akcie ma być „wiedza o archiwaliach" (Archivalienkunde): o dokumentacji narastającej u wytwórcy i następnie tworzącej w archiwum określone całości.

\section{Wersja mitiajewowska}

Bardzo śmiało na tzw. przedpole archiwalne, proponując własną wersję „nauki o akcie”, wychodzi K.G. Mitiajew, autor znanego radzieckiego podręcznika archiwistyki „Teoria i praktika archiwnogo dieła”". Praca upowszechniona został przede wszystkim w radzieckiej strefie nadzoru politycznego, tłumaczona w wielu krajach Europy środkowo-wschodniej: także i w Polsce. (w 1954 r.). Rozległy zasięg ujęcia usprawiedliwia w pewnym sensie porównanie mitiejewowskiej wykładni z roztrząsaniami Meisnera. Ewentualne podobieństwa nie mają znaczenia li tylko formalnego, aczkolwiek Mitiajew nie odwołuje się wprost do niemieckiego autora, opierając się przede wszystkim na opracowaniach rodzimych.

Pierwsza część książki Mitiajewa szczególnie zachęca do porównań z „Aktenkunde", wywołuje skojarzenia z nauką o akcie. Część ta, która w polskim tłumaczeniu brzmi „,nauka ogólna o dokumencie” określana była także jako "dokumentologia". Mitiajew zrezygnował co prawda z pogłębionych wywodów genetyczno-typologicznych nad systematyką czy analityką akt koncentrując się na zagadnieniach klasyfikacji dokumentów oraz przebiegu czynności aktotwórczych w kancelariach (biurach) urzędów. Podobnie natomiast jak Meisner uważał, że prześledzenie procesu narastania akt u wytwórcy wymaga uprzedniego zaznajomienia się $\mathrm{z}$ charakterem akt powstających w urzędach, organizacją urzędu itp.Tą drogą archiwista mógł lepiej poznać związki między aktami tworzącymi w archiwach zespoły archiwalne. Zbliżone do meisnerowskich, generalne założenia studiów aktoznawczych doprowadziły jednak Mitiajewa do innych wniosków.

Do najważniejszych wyróżników klasyfikacji akt zaliczył formalne kryterium pochodzenia dokumentów (akt) uwzględniające służbową (urzędowa)

\footnotetext{
${ }^{9}$ Moskwa 1946.
} 
proweniencję akt. W warunkach silnego scentralizowania zarządu nad życiem publicznym w Rosji radzieckiej po 1917 r. taki podział nasuwał się autorowi niejako automatycznie. Wobec zaniku instytucji samorządu oraz struktur obywatelskich wytwórcy akt posiadali w Związku Radzieckim z reguły status jednostek państwowych. Efektem takiego założenia było włączenie do tej samej grupy (służbowych) akt urzędów i przedsiębiorstw państwowych funkcjonujących w ramach podobnego, ścisłego nadzoru administracyjnego. Problem powstawał $\mathrm{w}$ momencie zastosowania tak rozumianego kryterium pochodzenia $\mathrm{w}$ stosunku do akt wytworzonych przed 1917 r. A. Mitiajew usiłował niestety nadać swej propozycji uniwersalne zastosowanie odnosząc je do materiałów starszych, narastające w całkowicie odmiennych uwarunkowaniach ustrojowych.

Pasywne, sformalizowane podejście do referowanych kwestii uwidoczniło się jednak i tu w postaci mocno uproszczonego, schematycznego obrazu funkcjonowania biurowości rosyjskiej. Autor próbuje go sprowadzić do zamkniętego, ściśle zaprogramowanego układu gwarantowanego przez hierarchiczne podporządkowanie władz i urzędów różnych szczebli. Proces aktotwórczy zawężony zostaje do dyplomatycznej analizy akt i drogi ich wędrówki wewnątrz danego urzędu (wytwórcy) lub pomiędzy urzędami. Odtworzenie wielopłaszczyznowych czy - jak chcieli holenderscy autorzy - organicznych więzi pomiędzy XIX i XX-wieczną produkcją aktową twórcy przyszłego zespołu archiwalnego, niezależnie od intencji autora, byłoby przy zastosowaniu takiej metody bardzo trudne.

Podobne wrażenia przynoszą rozdziały tyczące okresu sowieckiego. Mitiajew, piszący przecież o sprawach, których był świadkiem, nie widział jakby szans na bardziej dociekliwe, pogłębione drążenie zjawiska powstania i narastania akt w urzędach Związku Radzieckiego. Pomija zagadnienie wzajemnych relacji pomiędzy faktycznymi funkcjami i kompetencjami wytwórców akt a procesem aktotwórczym. Wszystkich radzieckich wytwórców akt potraktował jako biernego wykonawcę biurowych zaleceń odgórnych, jednolicie określających reguły funkcjonowania biurokracji tego państwa.

W dwadzieścia lat później Mitiajew ogłasza następna, poważniejszą publikację, w której - nie bacząc na znane doświadczenia niemieckie - podejmuje próbę zdefiniowania aktoznawstwa jako samodzielnej dyscypliny. Mitiajew po raz pierwszy zwraca uwagę na proces aktotwórczy ,jako czynnik świadomego utrwalania informacji”. Torował w ten sposób drogę do wyznaczania granic aktoznawstwa jako nauki i jego roli w całokształcie systemu informacyjnego ${ }^{10}$. Mitiajew, niejako nolens volens, znalazł się wśród tych autorów, którzy wyprowadzili radziecką archiwstykę zza ,żelaznej kurtyny”, skonfrontował ją z europejską literaturą archiwalną. Radzieckie propozycje teoretyczne, za sprawą ta-

${ }^{10}$ K.G. Mitiajew, Dokumentowiedienije, jego zadaczi i pierspiektiwy rozwitija, Moskwa 1964. 
kich autorów jak chociażby W.N. Awtokratow, A.W. Jełpatiewskij czy W.W. Caplin zaczynały być również inaczej niż dotychczas przyjmowane w krajach satelickich - w tym i w Polsce. Znane wydarzenia polityczne przełomu lat osiemdziesiątych i dziewięćdziesiątych przyspieszyły te procesy wnosząc do teorii archiwalnej całego obozu zasadniczo nowe jakościowo impulsy.

\section{Późniejsze modyfikacje}

Do europejskiej teorii archiwalnej nawiązywał mocno amerykański archiwista T.R. Schellenberg, autor zaliczanego do najpopularniejszych podręczników archiwistyki drugiej połowy XX w. ${ }^{11}$ Książka pisana była ze znakomitym wyczuciem nowoczesnych trendów archiwalnych. Autor nie poddał się jednak bezwiednie swojej intuicji współczesnego archiwisty. Szukał w przeszłych dokonaniach reformatorskich historycznego odniesienia dla swoich tez. Za przykład takiego podejścia do działalności archiwalnej niech posłuży schellenbergowska wizja powiązania zarządu aktami z zarządem archiwaliami. Schellenberg odwoływał się $\mathrm{m}$. in. do niemieckich rozwiązań okresu międzywojennego. Naukę o akcie Meisnera proponował zastapić koncepcją uwzględniającą obecność archiwistyki w systemie władzy i zarządzania, wyrażającą się jednością kancelarii, registratury i archiwum. Za bliskie swojej teorii uznał postulaty wysuwane w latach dwudziestych przez A. Brechta, który za podstawę lansowanych przez siebie reform zarządzania aktami przyjął merytoryczne zsynchronizowanie nadzoru nad czynnościami aktotwórczymi i archiwotwórczymi. Schellenberg głosił tezę, ze amerykański archiwista powinien przekształcić się z kustosza (strażnika skarbca archiwalnego) akt i archiwaliów w aktywnego zbieracza, gromadzącego odpowiednie informacje i źródła dokumentujące rzeczywistość. Zarząd aktami i zarząd archiwaliami coraz bardziej staje się integralną częścią systemu informacyjnego zarządzania ${ }^{12}$.

Młodsi autorzy amerykańscy (jak np. F.G. Ham i W.W. Moss), nawiązujący do Schellenberga, zdawali się kłaść akcent na atrybut unikalności pisanych źródeł gromadzonych w archiwach. Nawet we współczesnej formie, przy zastosowaniu nowoczesnej techniki reprograficznej, swój unikalny charakter archiwa zachowują. W początkach swego istnienia, przypominali, archiwa nacelowane były prawie wyłącznie na użytek władzy i państwa. Powoli sytuacja zaczęła się zmieniać - zgodnie z oczekiwaniami nauki i społeczeństwa. Przejawiało się to liberalizacją form udostępniania akt oraz demokratyzacją zasad gromadzenia, poszerzania zasobów o dokumentację odzwierciedlającą działalność różnych grup społecznych; dokumentacja tzw. prostego człowieka awansowana została również do rangi archiwaliów.

1 T.R. Schellenberg, Modern Archives: Principles and Techniques, Chicago 1957. W 1961 r. ukazała się niemiecka wersja tego podręcznika: Akten und Archivwesen in der Gegenwart. Theorie und Praxis, München 1961.

${ }^{12}$ Idem, Akten und Archivwesen..., op. cit., s. V, 8, 11. 
Dopełnieniem źródeł pisanych jest chociażby „mówiona historia” - oral history utrwalona na taśmach magnetycznych. Coraz większy odsetek dokumentacji najnowszej stanowią materiały wytwarzane lub przetwarzane za pośrednictwem komputerów, odczytywane maszynowo itp ${ }^{13}$.

Sprawa wpływu nowych technologii na rozwój form dokumentacyjnych podejmowana była, począwszy od lat pięćdziesiątych, przez czołowych przedstawicieli archiwistyki francuskiej R.H. Bautiera oraz M. Ducheina. W ostatnich dziesięcioleciach kwestia ta powracała z rosnącą intensywnością. Pojawiła się bardzo mocno na kongresie Stowarzyszenia Archiwistów Francuskich w styczniu 1990 r. W świetnym wystapieniu G. Weilla podniesiony został problem zmiany pojęcia dokumentu pisanego i weryfikacji metod ich opracowywania oraz rozwoju nowych technologii (informatyki). W coraz lepiej konstruowanych pomieszczeniach archiwalnych gromadzi się obok dokumentów pisanych (tekstowych) dokumenty dźwiękowe, audiowizualne, informatyczne. Permanentnego charakteru nabiera konieczność modyfikacji w zakresie klasyfikacji i kwalifikacji najnowszej dokumentacji, jej miejsca w procesie rozwoju źródła historycznego, porównania $\mathrm{z}$ tradycyjnymi formami przekazu ${ }^{14}$.

W dyskusjach ostatnich lat poświęconych współczesnej dokumentacji nietrudno również zauważyć silnego głosu archiwistów zachodnioniemieckich, których liczny zastęp wyróżniał się zazwyczaj na międzynarodowych konferencjach archiwalnych. Swoistym znakiem naukowej tożsamości niemieckiej archiwistyki, obecnej również w polskiej literaturze archiwalnej, opracowaniem uwiarygodniającym dokonania tego środowiska był obszerny, kilkutomowy podręcznik J. Papritza, opublikowany w połowie lat siedemdziesiątych w marburskiej Szkole Archiwalnej ${ }^{15}$. Artykuły tak znanych autorów, jak H. Booms, H. Dahm czy V. Buchholz niewątpliwie porządkują najnowszą teorię archiwalną na temat współczesnego dokumentu, nie wydaje się jednak aby ją jakoś specjalnie uatrakcyjniały, nadawały oryginalny ton przyszłym studiom archiwalnym.

${ }^{13}$ F.G. Ham, The archival edge, The American Archivist 1957, z. 1; W.W. Moss, Oral History Program Manual, New York 1975.

${ }^{14}$ La Gazette des Archives, z. 103, 1978.

${ }^{15}$ J. Papritz, Archivwissenschaft, Marburg 1976. 